\title{
Effects of Vitamin B12 Deficiency on Ejaculation Time in Patients with Chronic Gastritis
}

\author{
Kronik Gastritli Hastalarda Vitamin B12 Eksikliğinin Ejakulasyon Süresine Olan Etkileri
}

\author{
(D) Kaan Gökçen¹, (D) Pınar Gökçen² \\ ${ }^{1}$ Cumhuriyet University Faculty of Medicine, Department of Urology, Sivas, Turkiye \\ ${ }^{2}$ Cumhuriyet University Faculty of Medicine, Department of Gastroenterology, Sivas, Turkiye
}

\section{What's known on the subject? and What does the study add?}

Vitamin B12 deficiency may be observed in young men population due to chronic gastritis. Vitamin B12 is an important cofactor in synthesis of serotonin which acts a major role in ejaculation physiology. In our study; patients with B12 deficiency had lower intravaginal ejaculation time and higher premature ejaculation diagnostic tool scores. Men with vitamin B12 deficiency should be evaluated for sexual dysfunction especially premature ejaculation.

\begin{abstract}
Objective: Vitamin B12 deficiency is a common problem among chronic gastritis (CG) patients due to various factors. Vitamin B12 is involved in the regulation of the central nervous system and plays an active role in the synthesis of serotonin and catecholamines. This study aims to reveal the relationship between premature ejaculation (PE), which is a common sexual dysfunction in men, and B12 deficiency detected in patients with CG. Materials and Methods: A total of 155 patients enrolled in the study between May 2017 and December 2017 were evaluated in three groups; CG with and without B12 deficiency and healthy volunteers. The patients were assessed with intravaginal ejaculatory latency time (IELT) and the premature ejaculation diagnostic tool (PEDT) to evaluate PE. Depression status of the patients was evaluated by the Beck Depression Inventory (BDI-II).

Results: The mean age of the patients was $36.04 \pm 9.53$ years. Patients in the CG with B12 deficiency group had statistically significantly shorter IELT times $(137.12 \pm 93.58)$ and higher PEDT scores $(11.96 \pm 4.66)(p<0.001)$. Receiver operating characteristic analysis demonstrated a significant correlation between low levels of vitamin B12 and PE, and the cut-off value found in our study was $167.5 \mathrm{pg} / \mathrm{mL}$. No significant differences were determined in BDI-II scores between the groups, however, patients with CG and B12 deficiency had higher scores.

Conclusion: While the cause of vitamin B12 deficiency in CG patients is multifactorial, our study revealed a relationship between B12 deficiency and PE. Vitamin B12 deficiency was found to have significant relationship with IELT times and PEDT, while no significant association between vitamin B12 deficiency and depression was determined.
\end{abstract}

Keywords: Premature Ejaculation, Chronic Gastritis, Vitamin B12

Öz

Amaç: Vitamin B12 eksikliği kronik gastrit (KG) hastalarında çeşitli faktörlere bağlı sık gözlenen bir durumdur. Vitamin B12 santral sinir sisteminin regülasyonunda görev almakta olup özellikle serotonin ve katekolaminlerin sentezinde aktif rol oynamaktadır. Erkeklerde sık gözlenen bir seksüel disfonksiyon olan prematür ejakulasyon (PE) ile KG hastalarında saptanan vitamin B12 eksikliğinin ilişkisi çalışmamızda ortaya konmaya çalışılmıştır. Gereç ve Yöntem: Mayıs 2017 - Aralık 2017 tarihleri arasında çalışmaya dahil edilen toplam 155 hasta vitamin B12 eksikliği olan KG (grup 1), vitamin B12 eksikliği izlenmeyen KG (grup 2) ve sağlıklı gönüllülerden (grup 3) oluşan üç gruba ayrılmıştır. Erektil disfonksiyonu olmayan ve ortaağır depresyonu bulunmayan hastalar PE açısından değerlendirilmek için self-reported intravaginal ejaculatory latency time (IELT) ve five-item premature ejaculation diagnostic tool (PEDT) anketleri ile değerlendirilmiştir.

Correspondence: Kaan Gökçen MD, Cumhuriyet University Faculty of Medicine, Department of Urology, Sivas, Turkiye Phone: +90 3462580347 E-mail: drkaangokcen@gmail.com ORCID-ID: orcid.org/0000-0002-5507-1442

Received: 30.01.2019 Accepted: 13.03.2019

Cite this article as: Gökçen K, Gökçen P. Effects of Vitamin B12 Deficiency on Ejaculation Time in Patients with Chronic Gastritis. J Urol Surg 2019;6(3):244-251.

${ }^{\circ}$ Copyright 2019 by the Association of Urological Surgery / Journal of Urological Surgery published by Galenos Publishing House. 
Bulgular: Ortalama yaşları $(36,04 \pm 9,53)$ ve ortalama vücut kitle indeksleri $(24,21 \pm 2,59)$ olan hastalardan vitamin B12 seviyesi düşük olan KG hastalarında diğer gruplara göre anlamlı derecede kısa IELT süreleri $(137,12 \pm 93,58)$ ve yüksek PEDT skorları $(11,96 \pm 4,66)$ saptanmıştır $(p<0,001)$. Yapılan ROC analizine görede düşük vitamin B12 düzeyleri ile PE arasında anlamlı korelasyon saptanmış ve çalışmamıza ait cut-off değeri 167,5 $\mathrm{pg} / \mathrm{mL}$ olarak belirlenmiştir. Beck Depression Inventory-II anketine göre değerlendirilen hastalar arasında anlamlı fark saptanmamış; ancak vitamin B12'si düşük KG hastalarında diğer gruplara göre yükseklik saptanmıştır.

Sonuç: KG hastalarında vitamin B12 eksiklinin nedeni multifaktöriyel olmakla beraber çalışmamızda eksikliğinin görüldüğü olgular ile PE arasındaki ilişkisi ortaya konmuştur. Vitamin B12 eksikliği ile IELT süreleri ve PEDT arasında anlamlı ilişki bulunmuş olup depresyon durumları açısından anlamlı fark saptanmamıştır.

Anahtar Kelimeler: Prematür Ejakülasyon, Kronik Gastrit, Vitamin B12

\section{Introduction}

Chronic gastritis (CG) is defined as chronic inflammation of the gastric mucosa and is considered the most common endoscopic finding in the world's population (1). The most widely accepted classification was established by the Sydney System Working Party and it provided a well-accepted common language to clinicians for the evaluation of the biology and natural course of CG (2). On the other hand, the morphological evaluation of gastritis pivots on five key parameters. These parameters can be listed as chronic inflammation (plasma cells are dominant), activity level revealed by investigating the presence of polymorphonuclear leukocytes among mononuclear inflammatory cells, intestinal metaplasia currently diagnosed when the epithelium resembles the small intestinal phenotype, atrophy defined as the loss of normal mucosal glands, and the presence of Helicobacter pylori $(\mathrm{Hp})$ (positive or negative) $(3,4)$. The risk factors for gastric cancer are $\mathrm{Hp}$ infection, salt intake, smoking, alcohol consumption, family history of gastric cancer, atrophic gastritis, and intestinal metaplasia. Particularly atrophic gastritis and intestinal metaplasia are considered to be premalignant lesions of gastric cancer (5). For this reason, early diagnosis and management are important in preventing gastric cancer $(6,7,8)$. The majority of stomach cancers are classified as adenocarcinomas and, rare type of gastric cancers are lymphomas, gastrointestinal stromal tumors and carcinoid tumors.

Gastritis results in a decrease in acid secretion and bicarbonate production regardless of its etiology, and consequently, creates a reduction in mucosal blood flow, causing damage to the gastric epithelium and nutritional deficiencies, such as vitamin B12 (vit B12) and iron deficiency which are most commonly identified (9). Vit B12 is an essential water-soluble vitamin that is also known as cobalamin and requires adequate dietary intake and absorption to maintain its optimal level. Binding proteins such as haptocorrin, intrinsic factor (IF), transcobalamin II, and other specific cellular receptors are required for its absorption, transport, and cellular uptake. Clinically, vit B12 deficiency can manifest in a variety of forms ranging from asymptomatic clinical findings to macrocytic anemia, neuropsychiatric findings, cardiovascular diseases, and serious forms of cancer (10). Premature ejaculation (PE) is among the forms of sexual dysfunction that are commonly encountered in men and is defined in the diagnostic and statistical manual (DSM) of mental disorders, $5^{\text {th }}$ edition as a persistent or recurrent pattern of ejaculation occurring during partnered sexual activity within 1 minute after vaginal penetration and before the individual wishes present for at least 6 months and experienced in almost all or all (75-100\%) sexual activities (11). According to the most recent description of PE by the International Society for Sexual Medicine, lifelong PE where ejaculation takes place almost always before or within one minute of vaginal penetration since the first sexual experience and acquired PE where the Intravaginal ejaculation latency time (IELT) is significantly reduced with a duration of 3 minutes or less, are accompanied by a failure to delay ejaculation on nearly all vaginal penetrations, and consequently, stress, disappointment, and avoidance of sexual intercourse can be observed (12). Prevalence studies have reported the prevalence of PE to be approximately between 20\% and 30\%, however, most of these studies were conducted based on DSM-IV-TR, which offers unsatisfactory objective diagnostic criteria (13). Multinational prevalence studies investigating IELT in the general population have reported that the rate of patients who had an average latency time of 1 minute was 2.95\% (14). Studies done in Turkey and China with a focus on PE subtypes determined that the prevalence of lifelong PE was $2.3 \%$ and $3 \%$, and the prevalence of acquired PE was 3.9\% and $4.8 \%$, respectively $(15,16)$.

While the pathophysiology of PE has not yet been revealed, it is commonly thought that neurobiological and psychogenic factors, such as anxiety, penile hypersensitivity, and dysfunction of the 5-hydroxytryptamine (5-HT) receptors, play a major role in the etiology (17). In addition, it can also develop due to organic factors (thyroid disease, diabetes, prostatitis, medication use, glans hypersensitivity) and genetic predisposition $(18,19,20,21)$. 5-HT is known to be a potent inhibitor of ejaculation and a reduction in its levels is considered a significant risk factor for PE (22). Vit B12 is an important cofactor in nitric oxide (NO), homocysteine, and 5-HT metabolisms and provides the methyl group for the conversion of methionine to S-adenosylmethionine (SAM) (23). Therefore, low serum levels of vit B12 is considered closely related with PE. The aim of this study was to investigate the relationship between vit B12 deficiency that can develop secondary to $\mathrm{CG}$ and clinical manifestations of PE. 


\section{Material and Methods}

\section{Ethical Approval and Study Design}

Our study had a prospective design and was conducted with the voluntary participation of patients, who were referred to the Gastroenterology and Urology clinics at the Cumhuriyet University Hospital from other departments due to non-specific upper gastrointestinal system findings or to investigate the etiology of anemia and were diagnosed with CG based on oesophagogastroscopic biopsy (corpus and antrum) between the dates May 2017 and December 2017, and healthy volunteers. Approval was obtained from the ethics committee prior to the study and the patients were asked to sign a written consent prior to evaluation (ethics approval number: 2017-02/24).

\section{Patient Selection}

A total of 155 patients of whom 50 had a diagnosis of CG with vit B12 deficiency (group 1), 53 had a diagnosis of CG without B12 deficiency (group 2), and 52 were healthy volunteers (group $3)$, were assigned to three groups. Inclusion criteria were being in the age range 18-50, having a body mass index (BMI) $<30$, having monogamous and heterosexual intercourse for a period of six months, having normal erectile function, not having been treated for depression, not using alcohol and not smoking, not possessing any anatomical or endocrine causes for PE (malignity, diabetes, thyroid disease), not using medications, retardant condoms and topical agents, and not having undergone urogenital and pelvic surgery. Patients who described lifelong PE were excluded from the study. Detailed medical and sexual anamnesis was obtained from the participants, who were enrolled in the study, and urogenital examinations were performed. Then, they were asked to complete self-estimated IELT (the time between the start of vaginal intromission and the start of intravaginal ejaculation), Premature Ejaculation Diagnostic Tool (PEDT) which is a brief measure to assess PE, 15-Question International Index of Erectile Function (IIEF-5) and the Beck Depression Inventory (BDI-II) (0-13: minimal, 1419: mild, 20-28: moderate, 29-63: severe) in order to investigate their sexual and psychological states and the results were recorded $(24,25,26)$. According to the study criteria, volunteers with normal erectile function who obtained scores $\geq 22$ on the IIEF-5, and who presented minimal and mild depressive findings according to their scores on the 21-question BDI-II $(<19)$ were included in the study. In order to make a PE diagnosis, an IELT time $<3$ minutes and/or a five-question PEDT score $\geq 11$ scores were required (9).

\section{Measurement of Vitamin B12 Levels}

For all groups, venous blood samples were collected into EDTA tubes after approximately 12 hours of fasting. Centrifuged samples were stored at $-70{ }^{\circ} \mathrm{C}$ until analysis. Prepared samples were analyzed using the cobas e 601 (Roche Diagnostics, Turkiye) device with the immunoassay method to produce results in the form of picogram/milliliter $(\mathrm{pg} / \mathrm{mL})$. The reference value for vit B12 deficiency was $200 \mathrm{pg} / \mathrm{mL}$ and below.

\section{Chronic Gastritis Classification}

In classifying chronic inflammation, which is among the parameters used in the histopathological evaluation of CG, infiltration of less than $1 / 3$ of the mucosa with mononuclear cells was considered mild, denser infiltration that did not exceed $2 / 3$ of the mucosa was considered moderate, and infiltration of all layers of the mucosa was considered severe. In the evaluation of activity, infiltration of the lamina propria with few neutrophils was classified as mild, presence of more neutrophils in the mucosal layer that extend between surface and gland epithelial cells was classified as moderate, and dense infiltration with neutrophils accompanied by abscess or pits is classified as severe. Loss of gastric mucosal glands is considered atrophic gastritis (27).

\section{Statistical Analysis}

Statistical analyses were performed using IBM SPSS Statistics for Windows, (version 22, Armonk, NY, USA). Normally distributed data was analyzed using the Kolmogorov-Smirnov test. Data is given as mean \pm standard deviation (SD), with minimum and maximum values for continuous variables. The categorical data is defined as the number and percentage. Oneway ANOVA and post-hoc Tukey tests were used in parametric variables. Categorical data was analyzed using a chi-square test. Correlations between non-normally distributed data were assessed using the Pearson correlation coefficient (r). Statistical significance was considered at $p \leq 0.05$. The receiver operating characteristic curve cut-off value was estimated with the Youden index. In addition, the sensitivity, specificity, positive predictive value (PPV) and negative predictive value (NPV) were calculated.

\section{Results}

The mean age of the 155 patients was $36.1 \pm 9.5(19-50)$ and the mean BMI value was $24.2 \pm 2.5$ (18.3-29.8) with no difference between the groups ( $p=0.442$ and $p=0.073$, respectively). Clinical and demographic data of the patients are shown in Table 1. BDI and IIEF- 5 scores were determined to be similar across the three groups ( $p=0.406$ and $p=0.997$, respectively). Twenty-six patients in group 1, 10 patients in group 2 and 8 patients in group 3 had a IELT less than 3 minutes. Mean self-reported IELT values and vit B12 levels in group 1 were $137.1 \pm 93.5$ and $150.5 \pm 33.8$, respectively and significantly lower than those in the other two groups $(p<0.001)$, however, no differences were found between 
group 2 and group 3 ( $p=0.937$ and $p=0.336$, respectively). While the mean PEDT score in group 1 was significantly higher than in the other two groups $(11.9 \pm 4.6)(p<0.01)$, group 2 and group 3 presented similar results. No differences were found between the groups in terms of hemoglobin $(\mathrm{Hb}, \mathrm{g} / \mathrm{dL})$, hematocrit $(\mathrm{Hct}$, $\%$ ) and mean corpuscular volume values. Statistical power analysis done with regard to plasma vit B12 levels produced a value of $95.2 \%(\alpha=0.05)$.
Among oesophagogastroscopic biopsy findings that included activity, chronic inflammation, intestinal metaplasia, presence of $\mathrm{Hp}$, and $\mathrm{Hp}$ severity in group 1 and group 2 patients, only metaplasia demonstrated a significant difference $(p<0.05)$; whereas no statistical differences were detected between the three groups in terms of the other parameters. All the biopsy findings were normal in healthy group. Gastroscopic biopsy results of the patients are presented in Table 2.

Table 1. Clinical characteristics of the patient

\begin{tabular}{lllll}
\hline & Group 1 $(\mathbf{n}=\mathbf{5 0})$ & Group 2 $(\mathbf{n = 5 3 )}$ & Group 3 $(\mathbf{n = 5 2 )}$ & $\mathbf{p}$ \\
\hline Age $($ year) & $35.65 \pm 10.62$ & $37.79 \pm 9.94$ & $34.61 \pm 7.98$ & 0.442 \\
\hline BMI $\left(\mathrm{kg} / \mathrm{m}^{2}\right)$ & $23.66 \pm 1.99$ & $23.59 \pm 2.45$ & $24.25 \pm 2.92$ & 0.073 \\
\hline BDI & $688 \pm 3.47$ & $3.79 \pm 2.95$ & $2.25 \pm 2.27$ & 0.206 \\
\hline IIEF-5 & $24.31 \pm 1.16$ & $24.48 \pm 0.74$ & $24.36 \pm 1.06$ & 0.997 \\
\hline PEDT & $11.96 \pm 4.66^{\mathrm{a}, \mathrm{b}}$ & $6.59 \pm 4.56$ & $5.89 \pm 4.49$ & $0.007^{*}$ \\
\hline IELT & $137.12 \pm 93.58^{\mathrm{a}, \mathrm{b}}$ & $246.21 \pm 114.91$ & $248.57 \pm 124.06$ & $<0.001^{*}$ \\
\hline Vit B12 $(\mathrm{pg} / \mathrm{mL})$ & $150.54 \pm 33.85^{\mathrm{a}, \mathrm{b}}$ & $344.40 \pm 99.00$ & $323.49 \pm 92.19$ & $<0.001^{*}$ \\
\hline
\end{tabular}

BMI: Body mass index, IIEF-5: International Index of Erectile Function-5, BDI: Beck Depression Inventory, IELT: Intravaginal ejaculatory latency time, PEDT: Premature ejaculation diagnostic tool, Vit: Vitamin

${ }^{a} p<0.01$ when compared with group $2,{ }^{b} p<0.01$ when compared with group 3

Table 2. Oesophagogastric biopsy findings of chronic gastritis patients

\begin{tabular}{llll}
\hline Chronic inflammation & $\begin{array}{l}\text { Group } \mathbf{n} \\
\mathbf{n}(\%)\end{array}$ & $\begin{array}{l}\text { Group2 } \\
\mathbf{n}(\%)\end{array}$ & $\mathbf{p}$ \\
\hline Mild & $15(30)$ & $18(33.9)$ & 0.877 \\
\hline Moderate & $27(54)$ & $26(49.1)$ & - \\
\hline Severe & $8(16)$ & $9(16.9)$ & - \\
\hline Activity & & $21(39.6)$ & 0.650 \\
\hline None & $14(28)$ & $13(24.5)$ & - \\
\hline Mild & $14(28)$ & $14(26.4)$ & - \\
\hline Moderate & $17(34)$ & $5(9.5)$ & 0.502 \\
\hline Severe & $5(10)$ & & - \\
\hline Atrophy & & $46(86.7)$ & \\
\hline Absent & $41(82)$ & $7(13.3)$ & $0.015^{*}$ \\
\hline Present & $9(18)$ & & - \\
\hline Intestinal metaplasia & & $48(90.5)$ & \\
\hline Absent & $36(72)$ & $5(9.5)$ & 0.807 \\
\hline Present & $14(28)$ & & - \\
\hline Hp & & $16(30)$ & - \\
\hline Absent & $14(28)$ & $37(70)$ & 0.908 \\
\hline Present & $36(72)$ & $12(32.4)$ & - \\
\hline Hp severity & & $13(35.1)$ & \\
\hline Mild & $13(36.1)$ & & \\
\hline Moderate & $11(30.5)$ & $12(33.4)$ & \\
\hline Severe & & & \\
\hline Hp: & & \\
\hline
\end{tabular}


Parameters of both only CG patients and all participants including the healthy control group were investigated for correlations and it was found that serum vit B12 values were positively correlated with IELT values and negatively correlated with PEDT scores, with statistical significance. The results of analysis investigating correlations between vit B12 levels and other parameters are summarized in Table 3.

A receiver operating characteristic (ROC) curve analysis was referred to in order to determine the diagnostic value of serum vit B12 in all groups and the area under the curve was determined as 0.75 for vit B12 (95\% Cl: 0.590-0.910; $\mathrm{p}=0.002$ ). The cut-off value for vit B12 determined by the ROC analysis was $167.5 \mathrm{pg} / \mathrm{mL}$. The sensitivity and specificity of this value were $55.5 \%$ and $90.7 \%$, respectively. Based on this analysis, the PPV was calculated as 62.5 , the NPV as 88.1 , and accuracy as $83.1 \%$. The ROC curve analysis is demonstrated in Figure 1.

Table 3. Correlation between serum vitamin B12 levels and other parameters

\begin{tabular}{lllll}
\hline & \multicolumn{2}{l}{$\begin{array}{l}\text { Chronic gastiritis } \\
\text { patients (group 1 and 2) } \\
(\mathbf{n = 1 0 3 )}\end{array}$} & $\begin{array}{l}\text { Entire patients } \\
\text { (All groups) }(\mathbf{n = 1 5 5 )}\end{array}$ \\
\cline { 2 - 5 } & Vit B12 & Vit B12 & \\
\cline { 2 - 5 } & $\mathbf{r}$ & $\mathbf{p}$ & $\mathbf{r}$ & $\mathbf{p}$ \\
\hline Age & 0.03 & 0.411 & 0.10 & 0.177 \\
\hline BMI & -0.03 & 0.405 & -014 & 0.111 \\
\hline IELT & 0.47 & $<0.0001^{*}$ & 0.33 & $0.001^{*}$ \\
\hline PEDT & -0.50 & $<0.0001^{*}$ & -0.38 & $<0.0001^{*}$ \\
\hline BDI & 0.09 & 0.268 & -0.03 & 0.384 \\
\hline IIEF-5 & 0.10 & 0.231 & 0.14 & 0.110 \\
\hline
\end{tabular}

BMI: Body mass index, IIEF-5: International Index of Erectile Function-5, BDI: Beck Depression Inventory, IELT: Intravaginal ejaculatory latency time, PEDT: Premature ejaculation diagnostic tool, Vit: Vitamin

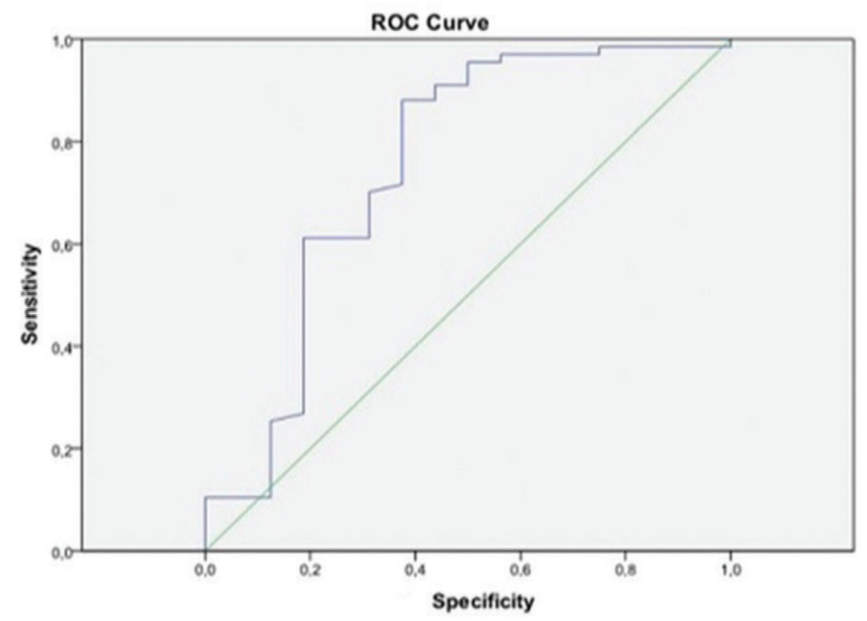

Figure 1. Receiver operating characteristic analysis for the diagnosis of premature ejaculation by plasma vitamin B12 levels

\section{Discussion}

Ejaculation is mediated by two primary neurological reflexes termed emission and expulsion, which involve different neural pathways. The sensation of orgasm is considered to be a distinct sensation that occurs simultaneously with these events. Emission is the movement of seminal fluid and sperm to the posterior urethra with sympathetic nervous systemmediated (T10-L2) rhythmic contractions of the seminal vesicle and prostate. In ejection, forcible expulsion takes place primarily under the control of somatic nerves (S2-S4) with the relaxation of the external urethral meatus in parallel to pulsatile contractions of the bulbocavernous and pelvic floor muscles (28). These complex pathways are enabled by the interaction of central serotonergic and dopaminergic neurons with secondary adrenergic, cholinergic, oxytocinergic, and gamma aminobutyric acid neurons (22). Serotonin (5-HT) found in the hypothalamus, brain stem, and the spinal cord plays an important role in the regulation of ejaculation. 5- $\mathrm{HT}$ acts as an ejaculation inhibitor and it delivers this effect through the $5-\mathrm{HT}_{1 \mathrm{~A}} 5-\mathrm{HT}_{1 \mathrm{~B}}$ and $5-\mathrm{HT}_{2 \mathrm{C}}$ receptors in particular (29). While the activation of the receptors $5-\mathrm{HT}_{2 \mathrm{C}}$ and $5-\mathrm{HT}_{1 \mathrm{~B}}$ at the postsynaptic level prolongs ejaculation time, activation of the $5-\mathrm{HT}_{1 \mathrm{~A}}$ receptor at the presynaptic level causes a decrease in serotonin release and negatively affects ejaculation time (30). Particularly in those with lifelong $\mathrm{PE}$, $5-\mathrm{HT}_{2 \mathrm{C}}$ hyposensitivity and/or $5-\mathrm{HT}_{1 \mathrm{~A}}$ receptor hypersensitivity have been considered responsible (22).

Aside from being an essential, a water-soluble vitamin that plays a role in DNA regulation and synthesis in the central nervous system, vit B12 also acts as a catalyzer and provides the methyl group in the conversion of homocysteine to methionine and in the subsequent events required for the formation of SAM (31). SAM is involved in the synthesis of serotonin and catecholamines and, vit B12 deficiency indirectly causes a negative effect on the production of serotonin (23). This role as a methyl provider is necessary for many methylation reactions in the brain and the 5-HT metabolism. Vit B12 therapy has also been reported to take effect by allowing communication between noradrenergic ( $\alpha 1$ and $\alpha 2)$ and serotonergic receptors (5- $\mathrm{HT}_{1 \mathrm{~A}}$ an $\mathrm{HT}_{2 \mathrm{~A} / 2 \mathrm{C}}$ ) (32).

Vit B12 deficiency can arise from insufficient dietary intake, disorders of cobalamin absorption, metabolism, or transport, and factors such as small intestinal malabsorption (33). The prevalence of vit B12 deficiency reported in the literature varies depending on the cut-off value and has been found to be $5-40 \%$ in the older population; whereas its prevalence based on age reveals rates of 3\% for ages $29-39,4 \%$ for ages $40-59$, and $6 \%$ for ages 60 and above $(34,35)$. The absorption of vit B12 involves active and passive mechanisms and a small portion (1$5 \%$ ) of free form is absorbed in the jejunum and ileum through passive diffusion independently from IF. This usually occurs due 
to vitamin intake at a supraphysiological dose and can result in a misevaluation of vit B12 levels absorbed from the stomach. Vit B12 deficiency can also be observed when antibodies against IF develop due to congenital, pernicious anemia-related, or gastric mucosal disorders. Furthermore, hypochlorhydria that develops in patients, who underwent gastrectomy or long-term use of proton-pump inhibitors, metformin, cholestyramine, and antacids, can also result in vit B12 deficiency (36). As opposed to studies that reported rates of combined pernicious anemia and vit B12 deficiency within the 15-25\% range, one study that investigated 181 patients with megaloblastic anemia and vit B12 deficiency determined a pernicous anemia prevalence of $65 \%$ $(37,38)$. These results raise the question whether there are other factors affecting vit B12 absorption besides autoimmune causes.

Our study determined significantly shorter self-estimated IELT times and higher PEDT scores in CG patients with low vit B12 levels compared to those in the other two groups $(p<0.001)$. According to the results of the ROC analysis, vit B12 levels had a strong negative correlation with PEDT and a strong positive correlation with IELT. The determined cut-off value was calculated as $167.5 \mathrm{pg} / \mathrm{mL}$ and was found to have high specificity. There exist very few studies in the literature investigating the relationship between vit $\mathrm{B} 12$ and $\mathrm{PE}$, and one study comparing $P E$ patients and a healthy control group determined significantly lower vit B12 levels in patients with PE (39).

It is known that patients with low levels of serum vit B12 experience depressive disorders due to disruption of serotonin synthesis and their treatment requires long-term vitamin replacement (40). On the other hand, a recent meta-analysis showed that vit B12 deficiency was encountered more frequently in advanced age and in women (41). In our study, patients with moderate and severe depression were specifically excluded, and although group 1 received a higher score on the $\mathrm{BDI}-\mathrm{Il}$ compared to the other groups, no statistically significant differences were determined between the groups $(p=0.206)$.

While gastritis is usually localized in the antrum in the case of Hp-related disease, stress, or medication use, inflammation in atrophic and autoimmune gastritis is usually localized in the fundus and corpus where parietal cells are found. Atrophy is also thought to develop independently of etiology (Hp gastritis or autoimmune) as a result of chronic inflammation. Half of patients with CG were shown to manifest atrophy at levels that varied throughout their lives (42). Studies done on older patients reported a higher prevalence of atrophy in those with vit B12 deficiency (43). Meanwhile, our study found a prevalence of atrophy and $\mathrm{Hp}$ of $16.5 \%$ and $70.8 \%$, respectively in our CG patients (group 1 and group 2). We think that our atrophy rates were similar across groups in contradiction to the literature because the patients enrolled in the study belonged to a younger age group. In evaluations of our CG patients according to the
Sydney classification, the prevalence of intestinal metaplasia was the only parameter that demonstrated a significant difference. In our study, the higher prevalence of intestinal metaplasia observed in group 1 patients was also related to corpus-predominant gastritis in the young population that did not manifest atrophy, and the group that had metaplasia was the one with lower serum vit B12 levels as expected.

We know in the light of recent genetic studies that vit B12 levels are affected by single nucleotide polymorphisms in multiple genes. Genetic variants can alter tissue levels of vit B12 by affecting the proteins involved in certain stages of absorption, cellular intake, and intracellular metabolism (44). Investigating the genetic factors will allow for more objective evaluation of vit B12 levels.

\section{Study Limitation}

The limitations of our study are the small sample size and inability to investigate plasma serotonine, IF antibody levels and tests associated with the genetic disorders that affect vit B12 absorption. Other limitation might be using self-estimated IELT measurement in our study, but self-estimated and stopwatchmeasured IELT are interchangeable and correctly assign PE status with higher sensitivity and specificity (45).

\section{Conclusion}

The measurement and evaluation of vit B12 levels are multifactorial and especially dietary intake, malabsorption, and genetic factors that affect absorption must be considered holistically. In our study, which aims to reveal the relationship between vit B12 levels and PE in the cohort of CG patients, CG patients with B12 deficiency demonstrated shorter IELT times and higher PEDT scores compared to the healthy control group and CG patients without B12 deficiency, regardless of CG etiology. Beyond the known symptoms of vit B12 deficiency, determining the effects of its clinical manifestations on ejaculation and depression plays a key role in improving the quality of life of the patients. There is a need for specific studies that will focus on etiology and publications that will corroborate the relationship between diseases such as CG that are frequently accompanied by vit $\mathrm{B} 12$ deficiency and $\mathrm{PE}$ and other sexual dysfunctions.

\section{Acknowledgements}

The authors have read the STROBE Statement and the manuscript was prepared and revised according to the STROBE Statement.

\section{Ethics}

Ethics Committee Approval: Approval was obtained from the ethics committee prior to the study and the patients were asked to sign a written consent prior to evaluation (no: 2017-02/24). 
Informed Consent: Approval was obtained from the ethics committee prior to the study and the patients were asked to sign a written consent prior to evaluation.

Peer-review: Externally peer-reviewed.

\section{Authorship Contributions}

Concept: K.G., Design: K.G., Data Collection and/or Processing: K.G., P.G., Analysis and/or Interpretation: K.G., P.G., Literature Research: K.G., P.G., Writing: K.G., P.G.

Conflict of Interest: The authors declare no competing financial or personal interests.

Financial Disclosure: No financial support.

\section{References}

1. Bertges LC, Dibai FN, Bezerra G, Oliveira ES, Aarestrup FM, Bertges KR. Comparıson between the endoscopic findıngs and the histologıcal diagnosis of antral gastrites. Arq Gastroenterol 2018;55:212-215.

2. Tytgat GN. The Sydney System: endoscopic division. Endoscopic appearances in gastritis/duodenitis. J Gastroenterol Hepatol 1991;6:223-234

3. Goodwin CS. The Sydney System: microbial gastritis. J Gastroentero Hepatol 1991;6:235-237.

4. Strickland RG. The Sydney System: auto-immune gastritis. J Gastroenterol Hepatol 1991;6:238-243.

5. Yoon $\mathrm{H}, \mathrm{Kim} \mathrm{N}$. Diagnosis and management of high risk group for gastric cancer. Gut Liver 2015;9:5-17.

6. Rokkas T, Pistiolas D, Sechopoulos P, Robotis I, Margantinis G. The long-term impact of Helicobacter pylori eradication on gastric histology: a systematic review and meta-analysis. Helicobacter 2007;12(Suppl 2):32-38.

7. Wang J, Xu L, Shi R, Huang X, Li SW, Huang Z, Li SW, Huang Z, Zhang G. Gastric atrophy and intestinal metaplasia before and after Helicobacter pylori eradication: a meta analysis. Digestion 2011;83:253-260.

8. Kong YJ, Yi HG, Dai JC, Wei MX. Histological changes of gastric mucosa after Helicobacter pylori eradication: a systematic review and meta-analysis. World J Gastroenterol 2014;20:5903-5911.

9. Zilli A, Cavalcoli F, Ciafardini C, Massironi S. Deficiency of micronutrients in patients affected by chronic atrophic autoimmune gastritis: A singleinstitution observational study. Dig Liver Dis 2019;51:505-509.

10. Lechner K, Födinger $M$, Grisold W, Püspök A, Sillaber C. Vitamin B12 deficiency. New data on an old theme. Wien Klin Wochenschr 2005;117:579591.

11. American Psychiatric Association. Diagnostic and statistical manual of mental disorders: DSM-5 ${ }^{\mathrm{TM}}$. 5th ed. Arlington, VA: American Psychiatric Publishing, 2013.

12. Serefoglu EC, McMahon CG, Waldinger MD, Althof SE, Shindel A, Adaikan G, Becher EF, Dean J, Giuliano F, Hellstrom WJ, Giraldi A, Glina S, Incrocci L, Jannini E, McCabe M, Parish S, Rowland D, Segraves RT, Sharlip I, Torres LO. An Evidence-Based Unified Definition of Lifelong and Acquired Premature Ejaculation: Report of the Second International Society for Sexual Medicine Ad Hoc Committee for the Definition of Premature Ejaculation. J Sex Med 2014;11:1423-1441.

13. Althof SE, McMahon CG, Waldinger MD, Serefoglu EC, Shindel AW, Adaikan PG, Becher E, Dean J, Giuliano F, Hellstrom WJ, Giraldi A, Glina S, Incrocci L, Jannini E, McCabe M, Parish S, Rowland D, Segraves RT, Sharlip I, Torres LO. An Update of the International Society of Sexual Medicine's Guidelines for the Diagnosis and Treatment of Premature Ejaculation (PE). Sex Med 2014;2:60-90
14. Waldinger MD, McIntosh J, Schweitzer DH. A five-nation survey to assess the distribution of the intravaginal ejaculatory latency time among the general male population. J Sex Med 2009;6:2888-2895.

15. Serefoglu EC, Yaman O, Cayan S, Asci R, Orhan I, Usta MF, Ekmekcioglu 0 , Kendirci M, Semerci B, Kadioglu A. Prevalence of the Complaint of Ejaculating Prematurely and the Four Premature Ejaculation Syndromes: Results from the Turkish Society of Andrology Sexual Health Survey. J Sex Med 2011:8:540-548.

16. Gao J, Zhang X, Su P, Liu J, Xia L, Yang J, Shi K, Tang D, Hao Z, Zhou J, Liang C. Prevalence and Factors Associated with the Complaint of Premature Ejaculation and the Four Premature Ejaculation Syndromes: A Large Observational Study in China. J Sex Med 2013;10:1874-1881.

17. McMahon CG, Abdo C, Incrocci L, Perelman M, Rowland D, Waldinger M, Xin ZC. Disorders of Orgasm and Ejaculation in Men. J Sex Med 2004;1:58-65.

18. Carani C, Isidori AM, Granata A, Carosa E, Maggi M, Lenzi A, Jannini EA. Multicenter study on the prevalence of sexual symptoms in male hypo- and hyperthyroid patients. J Clin Endocrinol Metab 2005;90:6472-6479.

19. Majzoub A, Arafa M, Al-Said S, Dabbous Z, Aboulsoud S, Khalafalla K Elbardisi $\mathrm{H}$. Premature ejaculation in type II diabetes mellitus patients: association with glycemic control. Transl Androl Urol 2016;5:248-254.

20. Lee JH, Lee SW. Relationship between premature ejaculation and chronic prostatitis/chronic pelvic pain syndrome. J Sex Med 2015;12:697-704.

21. Waldinger MD, Rietschel M, Nöthen MM, Hengeveld MW, Olivier B. Familial occurrence of primary premature ejaculation. Psychiatr Genet 1998;8:3740.

22. Waldinger MD. The neurobiological approach to premature ejaculation. J Urol 2002;168:2359-2367.

23. Bottiglieri T. Folate, Vitamin B12, and S-Adenosylmethionine. Psychiatr Clin North Am 2013;36:1-13.

24. Symonds T, Perelman MA, Althof SE, Giuliano F, Martin M, May K, Abraham L, Crossland A, Morris M. Development and validation of a premature ejaculation diagnostic tool. Eur Urol 2007;52:565-573.

25. Rosen RC, Cappelleri JC, Smith MD, Lipsky J, Peña BM. Development and evaluation of an abridged, 5-item version of the International Index of Erectile Function (IIEF-5) as a diagnostic tool for erectile dysfunction. Int J Impot Res 1999;11:319-326.

26. Beck AT, Steer RA, Brown GK. BDI-II, Beck depression inventory : second edition manual. The Psychological Corporation. San Antonio (TX), 1996; ISBN 01580183899780158018386

27. Fang JY, Liu WZ, Shi Y, Ge ZZ, Xiao SD. Consensus on chronic gastritis in China--Second National Consensus Meeting on Chronic Gastritis (14-16 September 2006 Shanghai, China). J Dig Dis 2007;8:107-119.

28. Master VA, Turek PJ. Ejaculatory physiology and dysfunction. Urol Clin North Am 2001;28:363-375

29. Giuliano F, Clément P. Serotonin and premature ejaculation: from physiology to patient management. Eur Urol 2006;50:454-466.

30. Ahlenius S, Larsson K. Specific involvement of central 5-HT1A receptors in the mediation of male rat ejaculatory behavior. Neurochem Res 1997;22:1065-1070

31. Gröber U, Kisters K, Schmidt J. Neuroenhancement with vitamin B12underestimated neurological significance. Nutrients 2013;5:5031-5045.

32. Brocardo PS, Budni J, Kaster MP, Santos ARS, Rodrigues AL. Folic acid administration produces an antidepressant-like effect in mice: evidence for the involvement of the serotonergic and noradrenergic systems. Neuropharmacology 2008;54:464-473.

33. Hunt A, Harrington D, Robinson S. Vitamin B12 deficiency. BMJ 2014;349:5226.

34. Allen LH. How common is vitamin B-12 deficiency? Am J Clin Nutr 2009;89:693-696 
35. Clarke R, Refsum H, Birks J, Evans JG, Johnston C, Sherliker P, Ueland PM, Schneede J, McPartlin J, Nexo E, Scott JM. Screening for vitamin B-12 and folate deficiency in older persons. Am J Clin Nutr 2003;77:1241-1247.

36. Lam JR, Schneider JL, Zhao W, Corley DA. Proton pump inhibitor and histamine 2 receptor antagonist use and vitamin B12 deficiency. JAMA 2013;310:2435-2342.

37. Wun Chan JC, Yu Liu HS, Sang Kho BC, Yin Sim JP, Hang Lau TK, Luk YW, Chu RW, Fung Cheung FM, Tat Choi FP, Kwan Ma ES. Pernicious anemia in Chinese: a study of 181 patients in a Hong Kong hospital. Medicine (Baltimore) 2006;85:129-138.

38. Dali-Youcef $N$, Andres E. An update on cobalamin deficiency in adults. OJM 2009;102:17-28.

39. Kadihasanoglu M, Kilciler M, Kilciler, Yucetas U, Erkan E, Karabay E, Toktas MG, Kendirci M. Relation between blood vitamin B12 levels with premature ejaculation: case-control study. Andrologia 2017:49.

40. Alpert JE, Mischoulon D, Nierenberg AA, Fava M. Nutrition and depression: focus on folate. Nutrition 2000;16:544-546.
41. Petridou ET, Kousoulis AA, Michelakos $T$, Papathoma P, Dessypris $N$, Papadopoulos FC, Stefanadis C. Folate and B12 serum levels in association with depression in the aged: a systematic review and meta-analysis. Aging Ment Health 2016;20:965-973.

42. Kekki M, Siurala M, Varis K, Sipponen $P$, Sistonen $P$, Nevanlinna HR. Classification principles and genetics of chronic gastritis. Scand J Gastroenterol Suppl 1987;141:1-28.

43. Dholakia KR, Dharmarajan TS, Yadav D, Oiseth S, Norkus EP, Pitchumoni CS. Vitamin B12 deficiency and gastric histopathology in older patients. World J Gastroenterol 2005;11:7078-7083.

44. Haggarty P. B-vitamins, genotype and disease causality. Proc Nutr Soc 2007;66:539-547.

45. Rosen RC, McMahon CG, Niederberger C, Broderick GA, Jamieson $C_{1}$ Gagnon DD. Correlates to the clinical diagnosis of premature ejaculation: results from a large observational study of men and their partners. J Urol 2007;177:1059-1064. 